\title{
Limbah Molas : Pemanfaatan sebagai Sumber Karbohidrat untuk Perkembangbiakan Mikroorganisme
}

\author{
Endah Wulandari ${ }^{1}$, Tami Idiyanti ${ }^{2}$, Ernawati Sinaga ${ }^{3}$ \\ ${ }^{1}$ Biokimia PSPD FKIK UIN Syarif Hidayatullah Jakarta \\ ${ }^{2}$ Lembaga Kimia Terapan LIPI Serpong \\ ${ }^{3}$ Biokimia Fakultas Biologi Universitas Nasional Jakarta
}

\begin{abstract}
Abstrak
Limbah molas merupakan hasil samping dari pabrik gula yang tidak dapat dikristalkan kembali. Salah satu kandungan limbah molas yaitu kaya akan karbohidrat. Salah satu upaya untuk memanfaatkan limbah molas yaitu dengan melakukan penelitian terhadap nutrisi yang masih terkandung dalam molas masih dapat dimanfaatkan. Penelitian ini bertujuan untuk mengetahui kemampuan mikroorganisme dalam memanfaatkan karbohidrat (glukosa) yang terdapat dalam limbah molas untuk perkembangbiakan. Mikroorganisme yang digunakan adalah jenis ragi yaitu Candida utilis, Endomycopsis fibuligera dan Saccharomyces cerevisiae. Waktu pengamatan yang dilakukan adalah $0,6,12,18,24,30$ jam dengan suhu inkubasi $37^{\circ} \mathrm{C}$. Pengamatan yang dilakukan meliputi : pengukuran berat biomassa dengan cara menimbang berat kering mikroorganisme, pengukuran konsentrasi glukosa limbah molas yang dimanfaatkan mikroorganisme dengan cara Somogyi-Nelson dan perhitungan tingkat efektifitas penggunaan molas terhadap pertkembangbiakan mikroorganisme. Hasil: Berat biomassa tertinggi dicapai oleh Saccharomyces cerevisiae dengan biomassa tertinggi $156,33 \mathrm{mg}$ dalam waktu $18 \mathrm{jam}$. Konsentrasi glukosa yang dimanfaatkan oleh Endomycopsis fibuligera lebih tinggi dibandingkan dengan mikroorganisme yang lain, yaitu dalam waktu 30 jam mencapai $3,13 \mathrm{mg} / \mathrm{mL}$ dan kemungkinan dengan bertambahnya waktu inkubasi masih mampu memanfaatkan glukosa lebih banyak. Mikroorganisme yang memiliki tingkat efektifitas dalam memnfaatkan limbah molas sebagai sumber glukosa adalah Saccharomyces cerevisiae dengan tingkat efektifitas 126,4 mL/mg berat biomassa dalam waktu 12 jam. Kesimpulan :Saccharomyces cerevisiae yang terbaik dalam pemanfaatan glukosa dari limbah molas untuk pertumbuhan biomassa.
\end{abstract}

Kata Kunci: limbah molas, biomassa, glukosa, mikroorganisme

\begin{abstract}
Waste molase was the result of beside from the sugar mill that had not became to crystal again. One of the waste content molase that has rich of carbohydrate. One of the effort to exploited of the waste molas that was by doing the research to nutrition which still implied in molase admit of to be exploited. This research aimed to know ability microorganism in exploited the carbohydrate (glucose) which there was in waste molas for propagation. The Microorganism used yeast that Candida utilis, Endomycopsis fibuligera and Saccharomyces cerevisiae. Perception time taken was $0,6,12,18,24,30$ hour with incubation temperature $37^{\circ} \mathrm{C}$. It was analysed for measurement of weight biomassa by considered drying to constant weight of microorganism, measurement of waste glucose concentration molase exploited mikroorganisme by SomogyiNelson and calculation of efectivity level could be used molase to microorganism propagation. Result : Weight biomass highest dried to constant weight by Saccharomyces cerevisiae conteined 156,33 mg during 18 hour. the Glucose concentration exploited by Endomycopsis fibuligera higher compared to microorganism other, that is during 30 hour $3,13 \mathrm{mg} / \mathrm{mL}$ and possibility with increased of of time incubation still could more exploited the glucose. Microorganism has been good efectivity level in exploited waste molas as glucose source was Saccharomyces cerevisiae with efectivity level $126,4 \mathrm{~mL} / \mathrm{mg}$ dried to constant weight conteined during 12 hour. Conclusion : In this case Saccharomyces cerevisiae the bestness in exploited glucose of waste molas for growth biomass.
\end{abstract}

Keywords :waste molase, biomass, glucose, microorganism 


\section{PENDAhUluAN}

Protein sel tunggal (PST) merupakan sumber produksi protein yang besar, sejak tahun 60-an pada saat terjadi kelaparan dibeberapa tempatdi dunia berkaitan dengan masalah ekonomi dan sosial, diikuti permasalahan peningkatan penduduk dunia yang tidak diimbangi peningkatan produksi makanan, telah dilakukan upaya pengembangan protein dari mikroorganisme sebagai sumber makanan sebagai alternatif pengganti protein daging (Ugalda dan Castrillo, 2005).

Pembudidayaan PST,Saccharomyces cerevisiae dengan menggunakan limbah nanas telah dilakukan, menunjukkan peningkatan 3-5 kali pada inkubasi 48 jam(Correia et.al, 2007).Penggunaan crude chicken waste pada Candida

utilis,Saccharomycescerevisiae,S.carlsbergensis terjadi peningkatan biomassa sekitar 36\% selama 48 jam (Hamed, 1993).Penggunaan PST dengan limbah jagung/sisa maizena dapat meningkatan secara bermakna kandungan gizi pada daging ayam boiler (Abalaka et al, 2010).Penggunaan beberapa limbah buahbuahan dalam pembudidayaan Saccharomyces cerevisiaeyang telah dilakukan, menunjukkan terjadi peningkatan PST 58,62\% (limbah pisang). 54,28\% (limbah delima), 50,86\% (limbah apel), 39,98\% (limbah mangga) dan 26,26\% (limbah jeruk manis) selama 24 jam (Mahnaaz et al, 2010).

Industri di Indonesia yang memproduksi karbohidrat sangat banyak, antara lain : pabrik gula, pabrik tapioka, pabrik terigu, pabrik sagu, pabrik tahu, pabrik mi, usaha kelapa parut dan lain-lain. Namun upaya mengatasi limbahlimbah dari industri tersebut belum maksimal. Limbah pabrik gula salah satu yang sulit diatasi karena rasa dan baunya kurang digemari masyarakat(Winarno, 1982).Pada penelitian ini digunakan limbah molas(produk samping dari pabrik gula gula yang belum dimanfaatkan secara maksimal) untuk pembudidayaan mikroorganisme sebagai PST.

Indonesia pernah menduduki urutan kedua sebagai penghasil gula setelah kuba. Pada saat ini walupun gula sebagian impor, namun industri-industri gula masih tetap bertahan untuk mencukupi kebutuhan konsumen. Di Indonesia diperkirakan diproduksi sebanyak 480.000 ton molas pertahun. Permasalahannya adalah limbah dari pabrik gula bila dibiarkan saja akan mencemarkan lingkungan sekitar. Upaya-upaya untuk memanfaatkan limbah molas sudah dilakukan antara lain digunakan sebagai bahan pembuat MSG (monosodium glutamat) melalui fermentasi, sebagai bahan pembuat alkohol, sebagai bahan minuman sirup dan pengganti selai untuk roti, namun kurang digemari masyarakat karena berbau tidak enak. Upaya lain yaitu digunakan sebagai bahan pakan ternak (Winarno, 1982).

Limbah molas merupakan hasil produk samping pabrik gula yang tidak dapat dikristalkan. Limbah molas kaya akan kandungan nutrisi yang dibutuhkan untuk pertumbuhan yaitu fruktosa, glukosa, protein dan vitamin, disertai pula molas mudah didapat di pabrik-pabrik gula (Jodoanindjoyo, 1980).

Berdasarkan hal tersebut di atas, penelitian ini dilakukan bertujuan untuk mengetahui kemampuan mikroorganisme memanfaatkan sumber karbohidrat (karbohidrat) yang terdapat dalam limbah molas untuk perkembangbiakan.

\section{a. Karbohidrat}

Karbohidrat merupakan komponen esensial semua organisme dan zat yang paling banyak penyusun sel. Fungsi karbohidrat adalah sebagai sumber energi (glukosa, pati, glikogen), membentuk struktur sel (glikoprotein), struktur penunjang tanaman (selulosa), penyusun cangkang crustacea (kitin), komponen asam nukleat. Glukosa merupakan sumber utama dalam metabolisme penghasil energi sel (Murray, 2003).

Fungsi glukosa untuk mikroorganisme dalam hal ini sebagai sumber energi dan cadangan energi, bahan pembentuk zat lain yang diperlukan mikroorganisme misalnya pembentuk gula pentosa penyusun RNA/DNA, pembentuk asam glukoronat, asam askorbat dan gliserol fosfat (Murray, 2003).

Karbon yang terdapat dalam karbohidrat terutama glukosa dapat digunakan sebagai penyusun molekul organik meliputi karbohidrat, protein, asam amin, lipid dan nukleotida. Fungsi dari molekul organik tersebut adalah memberikan memnyediakan cukup energi untuk 
mempertahankan fungsi tubuh atau sel. Di dalam sel mikrooragnisme glukosa mengalami metabolisme sehingga menyebabkan sel dapat bergerak dan memperbanyak diri atau berkembangbiak (Murary, 2003).

\section{b. Molas}

Molas merupakan hasil samping yang potensial dari industri gula. Molas berasal dari bahasa Rumania yang diartikan sebagai limbah akhir dari nira tebu yang telah dikristalkan berulang-ulang. Molas adalah fraksi yang tidak dapat dikristalkan lagi. Jumlah Molas dan komposisinya tergantung dari keadaan tebu dan proses pembuatan gula di pabrik (Jodoanindjoyo, 1980).

Molas mempunyai berbagai kandungan komponen kimia tertera pada tabel 1. Molas merupakan sumber energi yang murah karena mengandung gula sebanyak $50 \%$, baik dalam bentuk sukrosa, maupun dalam bentuk gula pereduksi. Gula-gula tersebut mudah dicerna dan diserap sel dan dapat digunakan untuk memperoleh energi (Hariyum, 1986).

Kandungan gula yang tinggi menyebabkan molas termasuk dalam kelompok bahan pangan yang awet. Hasil penelitian di pabrik-pabrik gula di Jawa menunjukkan bahwa bila limbah molas disimpan selama setahun, dengan suhu $30-35^{\circ} \mathrm{C}$, limbah molas hanya sedikit sekali mengalami kerusakan yaitu kehilangan gula yang difermentasikan sebanyak 2-3\% dari konsentrasi awal (Jodoanindjoyo, 1980).

\section{c. Mikroorganisme}

Penggunaan mikroorganisme untuk mengubah dan membuat makanan sudah dikenal sejak jaman purba. Mikroorganisme bersel satu sebagai sumber makanan untuk manusia mulai dikembangkan pada awal ke-19. Penggunaan mikroorganisme secara langsung sebagai bahan makanan manusia atau hewan sudah dilakukan. Penggunaan ragi roti oleh orang-orang Jerman selama perang dunia I. Penggunaan Candida utilis sebagai bahan makanan manusia atau hewan selama perang dunia II (Hariyum, 1986).

Pada tahun 1957 dilakukan percobaan pertama kali untuk membiakkan miroorganisme dengan skala besar. Produk yang dibiaakan tersebut dikenal dengan Single cell Protein
$(S C P)$ atau protein sel tunggal (PST). Protein sel tunggal yang berasal dari mikroorganisme bersel tunggal, Scrimshaw (1963) dan Wilson (1966) menamakan hasil sel yang telah dikeringkan tersebut sebagai PST. Tahun 1970 telah dikembangkan suatu standar pemakaian PST sebagai konsumsi manusia. PST yang saat ini sedang dikembangkan antara lain ganggang (Spirulina maxima, Chlorella sp dan Scenedesmus $s p$ ), jamur benang (Agaricus $s p$, aspergillus sp, Fusarium sp, Penicillium sp, Endomycopsis fibuligera, Trichosporon cutaneum), bakteri (Bacillus sp, Cellidomonas sp, Acinobacter calceaceticus, Nocardia sp) dan jenis-jenis ragi lainnya (Candida utilis, Candida lipolytica, Saccharomyces sp) (Hariyum, 1986).

Protein sel tunggal merupakan sumber protein yang berasal dari sel mikroorganisme. Protein sel tunggal ini dapat dimanfaatkan untuk kepentingan manusia secara langsung ataupun secara tidak langsung. Peranan mikroorganisme sebagai sumber protein baru, sangat erat hubungannya dengan sifat, bentuk dan lingkungannya yang sangat berbeda jika dibandingkan dengan jasad hidup lainnya (Sutopo, 1986).

Mikroorganisme yang digunakan dalam penelitian ini adalah jenis ragi yang sering digunakan di Indonesia, yaituCandida utilis, Saccharomyces cerevisiae dan Endomycopsis fibuligera. Hubungan kekerabatan dari ketiga mikroorganisme tersebut dapat dilihat pada tabel 2 (Nigam, 1998).

\section{METODE PENELITIAN}

\section{Tempat dan Waktu penelitian}

Penelitian dilakukan di Pusat Penelitian dan Pengembangan Kimia Terapan (P3KT-LIPI) Serpong.

\section{Alat dan Bahan \\ Alat-alat yang digunakan dalam penelitian : spektrofotometer, shaker, penangas air, mikropipet, cetrifuge dan peralatan glass. \\ Bahan yang digunakan limbah Molas yang berasal dari pabrik gula di Subang.Biakan Candida utilis, Saccharomyces cerevisiae dan Endomycopsis fibuliger, pereaksi glukosa (Somogy-Nelson) dan uji rancangan acak lengkap (RAL) (Yitosumarto, 1982).}


Tabel 1. Komposisi kimia molas (Hariyum, 1986)

\begin{tabular}{llcc}
\hline No. & Komponen & Kisaran (\%) & $\begin{array}{l}\text { Rata-rata } \\
(\%)\end{array}$ \\
\hline 1. & Air & $17-25$ & 20 \\
2. & Sukrosa & $30-40$ & 35 \\
3. & Glukosa & $4-9$ & 7 \\
4. & Fruktosa & $5-12$ & 9 \\
5. & Gula pereduksi & $1-5$ & 3 \\
6. & Karbohidrat lain & $2-5$ & 4 \\
7. & Abu & $7-15$ & 12 \\
8. & Nitrogen & $2-6$ & 4,5 \\
9. & Derivat nitrogen & $2-6$ & 5 \\
10. & Lilin, steroid, fodfolipid & $0,1-1$ & 0,4 \\
\hline
\end{tabular}

Tabel 2. Hubungan kekerabatan Candida utilis, Saccharomyces cerevisiae dan Endomycopsis fibuligera

\begin{tabular}{|c|c|c|c|}
\hline Regnum & Fungi & & \\
\hline Devisi & Eumycophyta & & \\
\hline Kelas & Ascomycetes & & \\
\hline Bangsa & Saccharomycetales & Saccharomycetales & Endomycetales \\
\hline Suku & Cryptococcaceae & Cryptococcaceae & Endomycetaceae \\
\hline Marga & Candida & Saccharomyces & Endomycopsis \\
\hline Jenis & Candida utilis & Saccharomyces cerevisiae & $\begin{array}{l}\text { Endomycopsis fibuligeral } \\
\text { Saccharomycopsis fibuligera }\end{array}$ \\
\hline Gambar & & & \\
\hline
\end{tabular}

\section{Cara kerja}

Pembiakan Mikroorganisme

Sel mikroorganisme (Candida utilis, Saccharomyces cerevisiae dan Endomycopsis fibuligera) murni ditanam dalam medium padat pada tabung reaksi, selanjutnya diperbanyak melalui inkubasi suhu $37^{\circ} \mathrm{C}$ selama 24 jam.

\section{Fermentasi dalam medium Molas}

Hasil pembiakan mikroorganisme, sebanyak 2 tabung selanjutnya diberi $10 \mathrm{~mL}$ akuades dan dikocok hingga homogen dengan bantuan handmixer. Setelah homogen biakan tersebut dituang dalam medium fermentasi yang berisi kandungan molas 1,25\%.

Pengamatan meliputi waktu inkubasi kultur selama $0,6,12,18,24$ dan 30 jam (duplo). Percobaan ini dilakukan pada $\mathrm{pH}$ awal 6 dalam suhu inkubasi $37^{\circ} \mathrm{C}$. Setiap hasil kultur dilakukan:(1) pengukuran berat biomassa mikroorganisme setelah dikeringkan (2) pengukuran konsentrasi glukosa dengan teknik Somogy-Nelson(Kleiner, 1954).Pengukuran konsentrasi glukosa diperoleh melalui kurva standar glukosa $(\mathrm{mg} / \mathrm{mL})$ yang dibuat sebelumnya.Untuk mendapatkan hasil konsentrasi glukosa yang dimanfaatkan mikroorganismedihitung melaluiselisih darikonsentrasi glukosa waktu awal (nol jam) dengan konsentrasi yang diperoleh pada setiap pengamatan waktu inkubasi.(3)Serta dilakukan pengukuran efektifitas penggunaan molas. Perhitungan ini diperoleh melalui perbandingan antara jumlah biomassa dengan konsentrasi glukosa yang dimanfaatkan oleh mikroorganisme. 


\section{HASIL DAN PEMBAHASAN}

\section{Pengukuran berat biomassa mikroorganisme}

Data pengamatan pertumbuhan biomassa mikroorganisme pada medium molas dapat dilihat pada gambar 1.

Pertumbuhan tertinggi berturut-turut dicapai Saccharomyces cerevisiae dengan biomassa tertinggi 156,33 $\mathrm{mg}$ dalam waktu 18 jam, Candida utilis dengan biomassa tertinggi $102,5 \mathrm{mg}$ dalam waktu 30 jam dan Endomycopsis fibuligera dengan biomassa tertinggi 101, $46 \mathrm{mg}$ dalam waktu 30 jam.

Hasil anallisis statisitik menunjukan bermakna berbeda nyata pada pertumbuhan biomassa ketiga jenis ragi pada medium molas, baik pada faktor jenis ragi maupun pengaruh lamanya waktu inkubasi. Saccharomycescerevisiaememiliki kecepatan pertumbuhan lebih cepat, hal ini disebabkan kemampuannya untuk memanfaatkan karbon yang terdapat dalam limbah molas untuk metabolisme dan pembelahan sel lebih cepat(Murray, 2003). Pemanfaatan molas oleh Endomycopsis fibuligera dalam pertumbuhan sel sangat lamban.Pemanfaatan karbon digunakan bukan memperbanyak jumlah sel, namun memperbanyak jumlah percabangan membentuk struktur seperti benang kusut (hipa).Sacharromyces cerevisiae langsung melakukan pembelahan langsung, melakukan pembelahan terus menerus dan penambahannya secara defernesial sehingga sel cepat bertambah. Candida utilis, demikian pula melakukan percabangan namun selanjutnya cepat lepas dari sel induk (Pelczar, 1986).

\section{Pengukuran konsentrasi glukosa (Somogy- Nelson)}

Data konsentrasi glukosa yang dimanfaatkan oleh mikroorganisme tercantum pada gambar 2.

Konsentrasi glukosa yang dimanfaatkan oleh Endomycopsis fibuligera lebih tinggi dibandingkan dengan mikroorganisme yang lain, yaitu pada waktu 30 jam mencapai $3,13 \mathrm{mg} / \mathrm{mL}$ dan kemungkinan dengan bertambahnya waktu inkubasi masih mampu memanfaatkan glukosa lebih banyak. Sedangkan kadar glukosa yang dikonsumsi oleh Candida utilis tertinggi pada waktu 24 jam yaitu 2,17 dan Saccharomuces cerevisiae tertinggi pada waktu 24 jam yaitu 1,45. Pada waktu 30 jam kedua mikroorganime tersebut mengalami penurunan dalam pemanfaatan mulai penurunan. Analisis statistik pada konsentrasi glukosa yang dimanfaatkan oleh mikroorganisme baik faktor jenis ragi dan waktu inkubasi memberikan pengaruh bermaknaberbeda sangat nyata.

Endomycopsis fibuligera mempunyai kemampuan hidrolisis yang lebih baik dibandingkan Candida utilis dan Saccharomyces cerevisiae, karena mempunyai enzim $\alpha$-amilase dan $\beta$-amilase sedangkan Candida utilis dan Saccharomyces cerevisiae hanya memiliki enzim glukoamilase. Pengujian konsentrasi glukosa yang dimanfaatkan oleh mikroorganime ini dimaksud untuk mengetahui jumlah karbon yang diserap oleh ketiga mikroorganisme tersebut sebagai sumber energi untuk meningkatkan pertumbuhannya. Terbukti bahwa baik Candida utilis, Endomycopsis fibuligera dan Saccharomyces cerevisiae dapat memanfaatkan limbah molas sebagai sumber karbon untuk pertumbuhannya. Hal ini juga mempertegas bahwa gula yang terdapat dalam limbah molas dapat langsung dimanfaatkan oleh mikroorganisme (Hariyum, 1986).

Endomycopsis fibuligera paling banyak mengkonsumsi glukosa pada medium limbah molas dibandingkan Candida utilis dan Saccharomyces cerevisiae.Hal ini dikarenakan sel Endomycopsis fibuligera lebih banyak membutuhkan nutrisi seperti glukosa yangakan digunakan untuk membentuk percabangan dan perpanjangan miselium dalam satu selnya. Berbeda dengan Candida utilis dan Saccharomyces cerevisiae dimana sel pembelahannya langsung cepat lepas. Sehingga satu sel ragi membutuhkan karbon lebih sedikit hanya untuk pembelahan saja(Pelczar, 1986).

\section{Perhitungan tingkat efektifitas penggunaan molas}

Hasil perhitungan tingkat efektifitas penggunaan media limbah molas dapat dilihat pada gambar 3. 


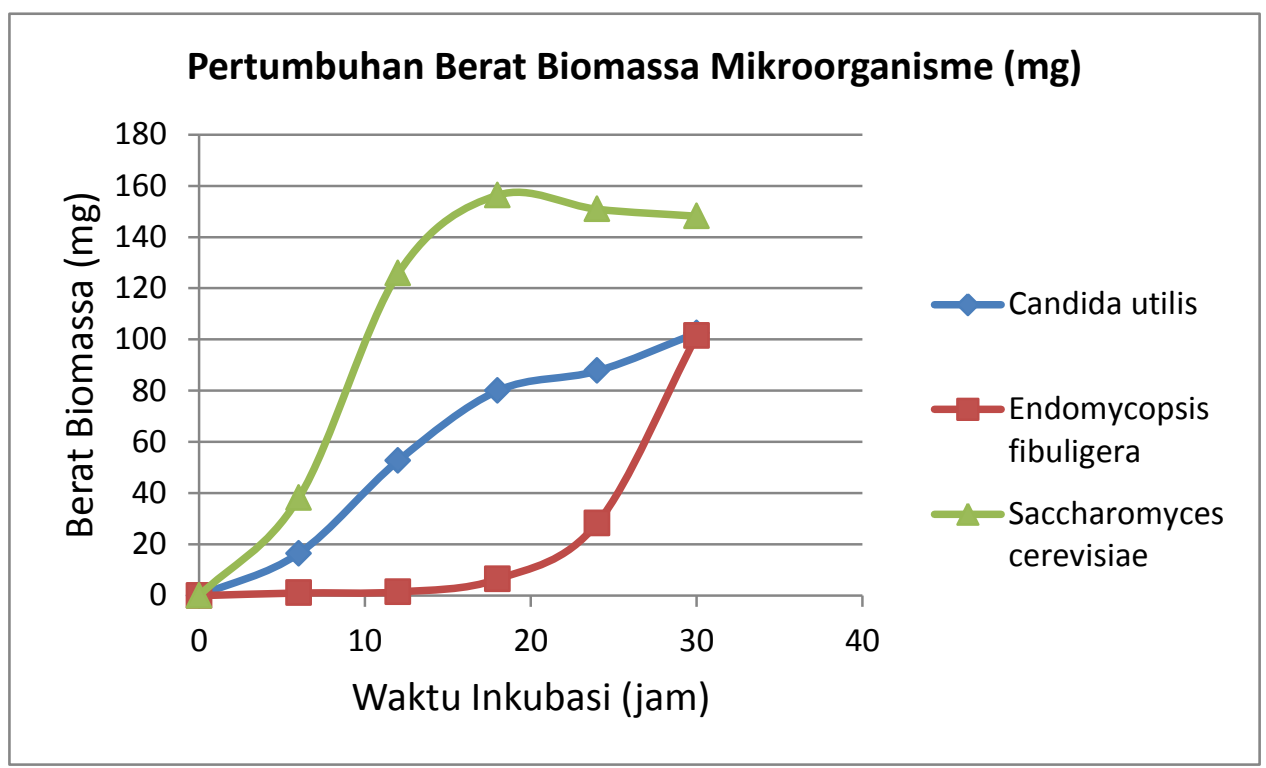

Gambar 1. Pertumbuhan berat biomassa mikroorganisme setelah memanfaatkan limbah molas

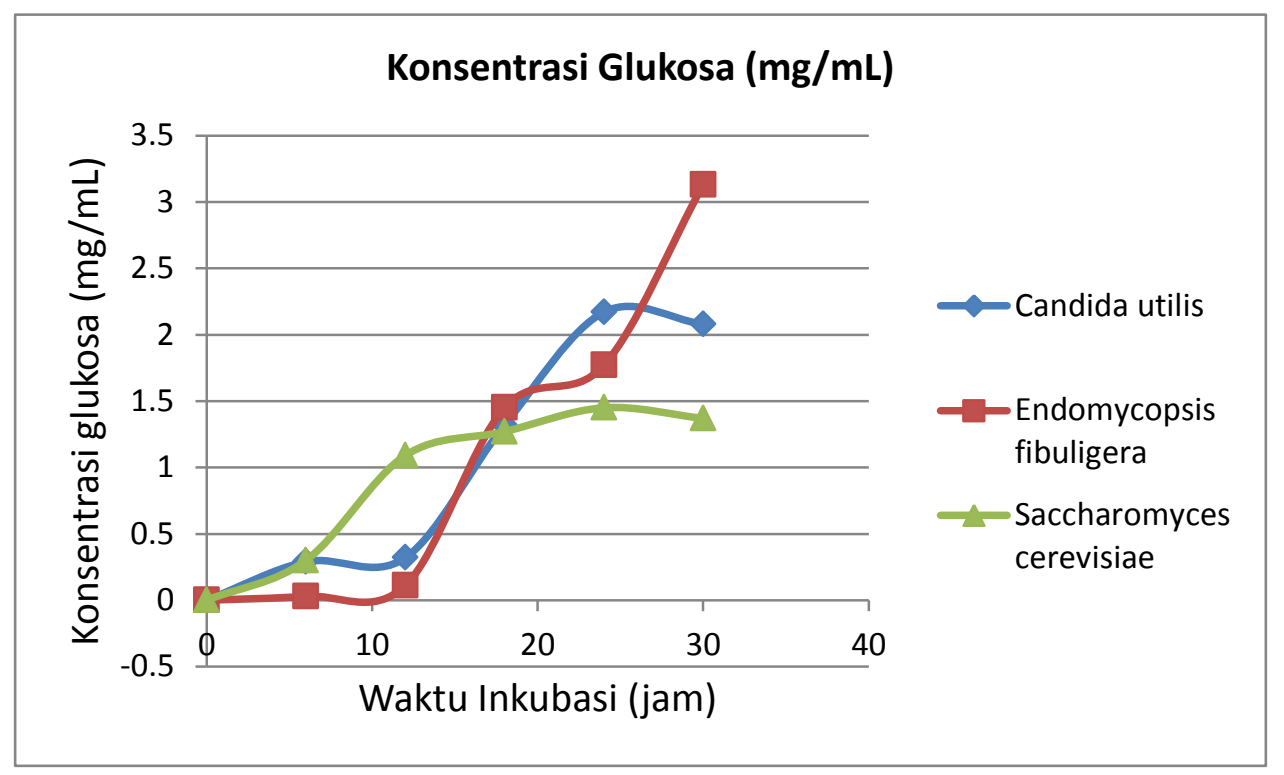

Gambar 2. Konsentrasi glukosa dari limbah molas yang dimanfaatkan oleh mikroorganisme

Mikroorganisme yang memiliki tingkat efektifitas tinggi dalam pemanfaatann limbah molas sebagai sumber karbon adalah Saccharomyces cerevisiae dengan efisiensi 126,4 mL dalam waktu 12 jam; Candida utilis dengan efisinesi $69,78 \mathrm{~mL}$ dalam waktu 12 jam dan Endomycopsis fibuligera dengan efisiensi $33,86 \mathrm{~mL}$ dalam waktu 6 jam. Pada analisis statistik perhitungan efektifitas pemanfaatan molas untuk pertumbuhan biomassa baik faktor jenis ragi dan lama waktu inkubasi memberikan pengaruh bermakna berbeda sangat nyata. Dari ketiga mikrroganisme tersebut menunjukkan bahwa Saccharomyces cerevisiae yang terbaik dalam tingkat efektifitas pemanfaatan limbah molas dalam pertumbuhan biomassa. Hal ini desebabkan karena Saccharomyces cerevisiae mampu memanfaatkan secara optimal karbon dan nutrisi lain dalam limbah molas bagi pertumbuhan sel. Pada Endomycosis fibuligera 


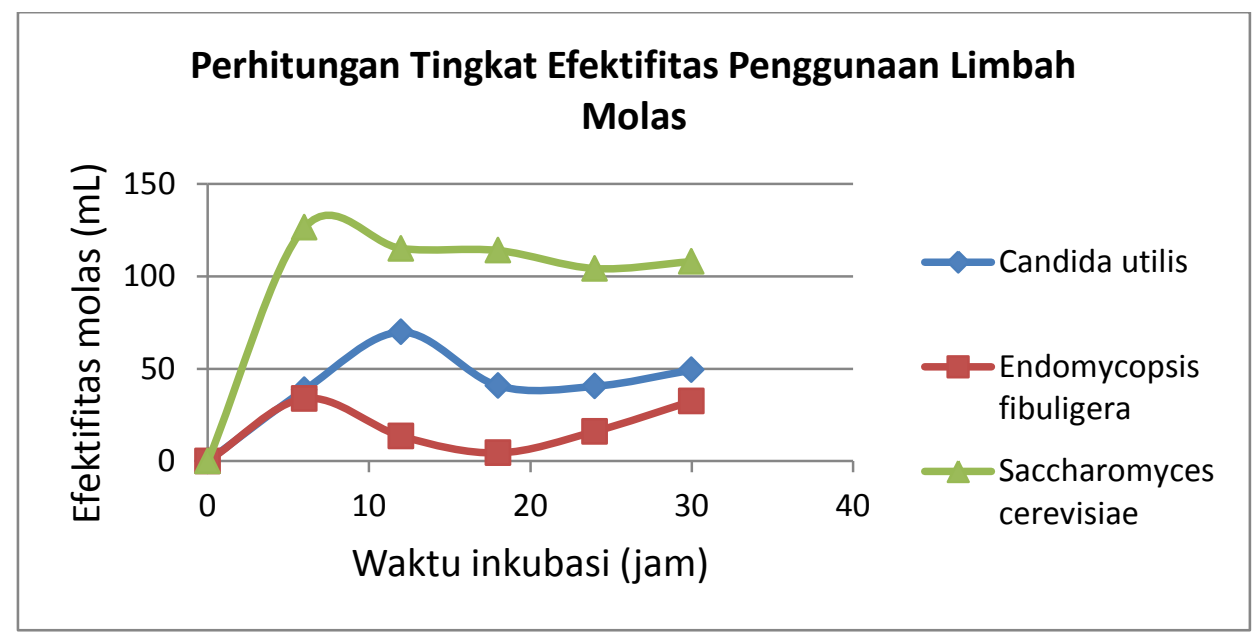

Gambar 3. Perhitungan tingkat efektifitas penggunaan limbah molas

yang memanfaatkan glukosa dari limbah molas tidak untuk memperbanyak sel namun dimanfaatkan untuk melakukan percabangan dan perpanjangan miselium (Pelczar, 1986).

\section{KESIMPULAN DAN SARAN}

\section{Kesimpulan}

Candida utilis, Endomycopsis fibuligera dan Saccharomyces cerevisiaedapat memanfaatkan limbah molas sebagai sumber karbon dalam pertumbuhan biomassa. Saccharomyces cerevisiae yang pertumbuhan biomassanya lebih tinggi dan lebih cepat serta memiliki tingkat efektifitas sangat tinggi dalam menggunakan karbohidrat (glukosa) dari limbah molas

\section{Saran}

1. Perlu penelitian lanjutan dalam memfaatkan nutrisi selain karbon (glukosa) misalnya protein, vitamin dan asam amino yang terdapat dalam limbah molas.

2. Perlu dilakukan pula penelitian terhadap limbah-limbah lain antara lain limbah tapioka, terigu, tahu dan sebagainya untuk perkembangbiakan PST.

\section{DAFTAR PUSTAKA}

1. Abalaka ME and Daniyan S.Y. Improving the Growth of Broilers Using Maize Waste Enriched with Groundnut Paste and Single Cell Protein. Adv. Environ. Biol., 4(3): 2010,515-519
2. Correia R, Magalhaes M and Macedo G. Protein enrichment of pineapple waste with with Saccharmyces by solid state bioprocessing. Journal of Scientific \& Industrial Research. Vol 66. March 2007.pp 259-262

3. Ecology and Evolutionary Biology Plant. Candida utilis, Endomycopsis fibuligera dan Saccharomyces cerevisiae L, University of Connecticut.http://Florawww.eeb.uconn.edu/acc num/199500162.html, January 23, 2008.

4. Hamed A. Biosynthesis of single cell protein (SCP) by yeast from crude chicken waste. Qatar Univ Sci J. 1993. 13(2); 238-242

5. Hariyum A : Pembuatan protein sel tunggal, PT Waca Utama Pramesti, 1986, h1

6. Jodoanidjoyo RM. Said G dan Hartoto L: Biokonversi (transformasi mikrobial), Dep Pendidikan dan Kebudayaan, Dirjen Pendidikan Tinggi, PAU-Bioteknologi, IPB, 1986, h131

7. Kleiner I Dotti, Laboratory instruction in Biochemistry, Fourth edition, St.Louis. The CV Mosby company, 1954

8. Mahnaaz K, Shaukat SK, Ahmed Z and Tanveer A. Production of single cell Protein from Saccharomyces cerevisiae by utilizing fruit waste. Nanobiotechnica uneversale. Vol.1(2), 2010, 127-132

9. Murray RK. Granner DK dan Rodwell VW. Harper's illustrated Biochemistry. 27 th edition. United Stated : McGraw-Hill. 2003. h.14

10. Nigam, J. N. (1998). Single cell protein from pineapple cannery effluent, World Journal Microbiology and Biotechnology, 14, 693-696. Nigam, J. N. (1998). Single cell protein from 
pineapple cannery effluent, World Journal Microbiology and Biotechnology, 14, 693-696.

11. Pelczar MJR : Dasar-dasar mikroorganisme, UIpress, Jakarta, 1986, h.189

12. Sutopo Rs. Purwati S. Syafei danRahmat : Pemanfaatan lumpur serat hasil buangan pabrik pulp dan kertas sebagai media produksi protein sel tunggal (PST), Balai besar penelitian dan pengembangan industri selulosa, Bandung, 1986, h1

13. Ugalda UO and Castrillo JI. Single Cell Proteins from Fungi and Yeasts. Biochemistry Devision. Faculty of Chemistry. University of Manchester. 2005

14. Winarno FG. Fardiaz S Dan Fardiaz D : Pengantar teknologi Pangan, PT Gramedia, Jakarta, 1982, h10

15. Yitnosumarto S. Percobaan (perancangan, analisis dan inter pretasinya). Jakarta: PT Gramedia Pusaka Utama. 1982. h.42 